\title{
Treatment of oral hemangioma with sclerotherapy: case report
}

\section{Tratamento de hemangioma oral com escleroterapia: relato de caso}

\author{
Salomão Israel Monteiro Lourenço Queiroz', Gleysson Matias de Assis², Valéria Damasceno Silvestre', \\ Adriano Rocha Germano², José Sandro Pereira da Silva²
}

\begin{abstract}
Hemangiomas are benign neoplasms that are common in the head and neck, but relatively rare in the oral cavity. They can cause esthetic and functional impairment, depending on location. The most common site is the upper lip, but they can occur in other areas, such as the tongue, buccal mucosa and palate. Treatment is primarily dependent on correct diagnosis of the lesion and on its anatomic location. The purpose of this article is to provide a description of a case of a hemangioma on the upper lip, treated by therapeutic sclerosis with monoethanolamine oleate (Ethamolin ${ }^{\circledR}$ ), covering clinical characteristics and methods for diagnosing these lesions. Precise diagnosis and appropriate therapeutic management resulted in satisfactory esthetic and functional results, with total regression of the lesion and no signs of relapse at 1-year follow-up.
\end{abstract}

Keywords: hemangioma; sclerotherapy; neoplasms, vascular tissue; mouth; lip.

\section{Resumo}

O hemangioma é uma neoplasia benigna comum na região de cabeça e pescoço, e é relativamente rara na cavidade oral, podendo causar prejuízo estético e funcional a depender da sua localização. Sua localização mais frequente é o lábio superior, mas pode ocorrer em outras regiões, como língua, mucosa jugal e palato. O seu tratamento depende, principalmente, do correto diagnostico da lesão, bem como da localização anatômica da mesma. A proposta deste artigo é relatar um caso de hemangioma em lábio superior tratado com esclerose terapêutica com oleato de monoetanolamina (Ethamolin ${ }^{\circledR}$ ), considerando as características clínicas e os métodos de diagnóstico desta lesão. Por meio de um diagnóstico preciso e uma conduta terapêutica adequada, o caso apresenta-se com um acompanhamento de um ano, sem sinais de recidiva, e com um resultado estético funcional satisfatório, com regressão total da lesão.

Palavras-chave: hemangioma; escleroterapia; neoplasias de tecido vascular; cavidade bucal; lábio.

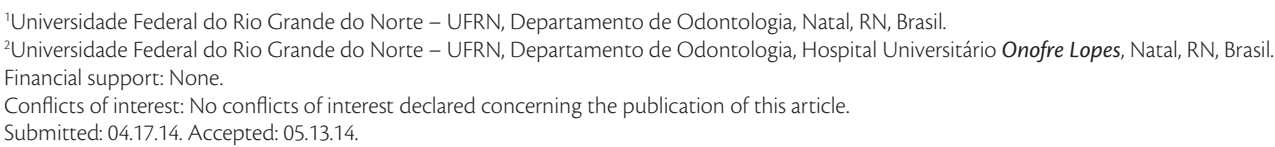




\section{INTRODUCTION}

In 1982, Mulliken and Glowacki ${ }^{1}$ proposed a classification system for vascular lesions based on the cellular method, dividing these lesions into two types. The first type exhibits endothelial proliferation (hemangioma), with rapid growth, followed by gradual involution, meaning that $90 \%$ of cases resolve themselves before 9 years of age, and 5 to $10 \%$ occur in children up to 1 year old. ${ }^{2}$ The second type does not exhibit proliferation of the endothelium (vascular malformation), is present at birth and remains throughout life, affecting around 0.3 to $1 \%$ of newborn infants. ${ }^{2}$

A hemangioma is a common and benign neoplasm of the head and neck that relatively rarely lasts beyond 9 years of age. In the oral and perioral region it can cause esthetic and functional impairment, depending on location. ${ }^{2,3}$ The most common site is the lips, ${ }^{4}$ but other areas, such as the tongue, buccal mucosa and palate have also been described. ${ }^{3,5,6}$ Peak incidence is described soon after birth or in early infancy; but some cases have onset in adulthood. ${ }^{2,3,6,7}$

Clinical definition is a fundamental part of diagnosis, because in cases of extensive involvement, surgery may cause difficult to control transoperative bleeding. Therefore, a combination of detection of medical signs on examination and supplementary test results can provide absolutely conclusive diagnoses in the majority of cases. ${ }^{8,9}$

Clinically, hemangiomas present as swellings filled with blood or as red or bluish-purple discolorations that, depending on the depth of the lesion and the localization of the affected tissue, disappear momentarily on digital compression or diascopy. This is the clinical method for establishing diagnosis. ${ }^{8,9}$

Size is variable, ranging from a few millimeters to several centimeters and may cause facial asymmetry. Physical appearance is as a flat or elevated lesion which may be in the form of a macule, papule, nodule or tumor, is normally pulsatile and has a higher temperature than adjacent tissues. Consistency is elastic or fibrous, depending on the amount of connective tissue interposed within the vascular spaces. $^{2}$

Sclerotherapy is one treatment option that has been used with great success on small lesions located in sites with esthetic impact, where surgery could leave unattractive scarring. ${ }^{6,10-12}$ The objective of this article is to describe a case of a female patient with a hemangioma of the upper lip that was treated with therapeutic sclerosis (monoethanolamine oleate), covering clinical characteristics and diagnostic methods.

\section{DESCRIPTION OF CASE}

A 13-year-old brown-skinned female patient (M.E.N.), presented at the oral diagnosis service with a primary complaint of a 'blue-colored lesion' located on the upper lip.

During history taking, the patient reported that she had noticed the lesion more than 2 years previously. She had acquired the habit of biting her lip and had noticed that the size of the lesion increased when she had been crying or bathed in a swimming pool. On physical examination, little facial asymmetry was evident, probably because the patient had very prominent lips (Figure 1). Intraoral physical examination revealed a lesion that was firm on palpation and purple colored, with sessile attachment, smooth skin and intact mucosa (Figure 2).

The lesion was painless and exhibited no other symptoms even when manipulated. During a diascopy test the purple color was observed to fade. Doppler ultrasonography revealed echographic abnormalities in subcutaneous tissue of the upper lip, left of the midline, containing tissue with a hypoechoic echotexture that was discreetly heterogenous, with a regular outline and well-defined limits, measuring $3.0 \times 1.0 \times 1.0 \mathrm{~cm}$ in diameter, with discrete dilation of vessels with low resistance flow on Doppler imaging, suggesting a diagnosis of hemangioma (Figure 3 ).

Once the echographic examination had confirmed the vascular nature of the lesion with slow continuous flow and had identified its location, the decision was taken to employ sclerotherapy with $0.05 \mathrm{~g} /$ $\mathrm{mL}$ of monoethanolamine oleate, administered on three occasions via slow infiltration of $2 \mathrm{~mL}$ into the

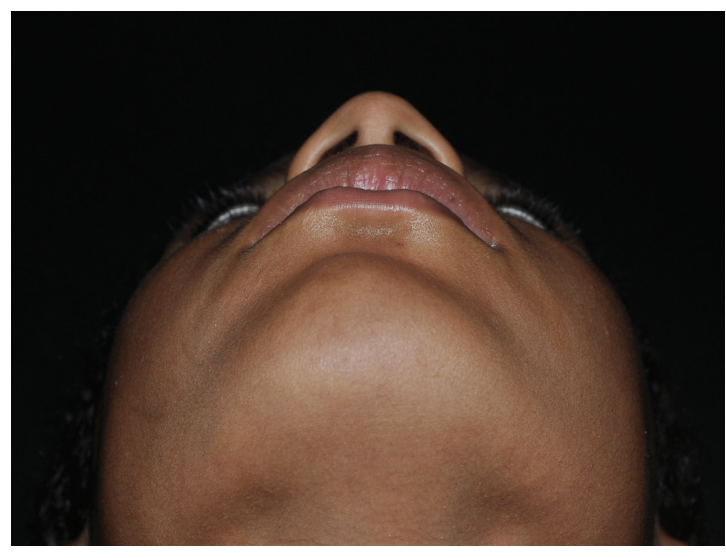

Figure 1. Physical examination, extraoral view. 


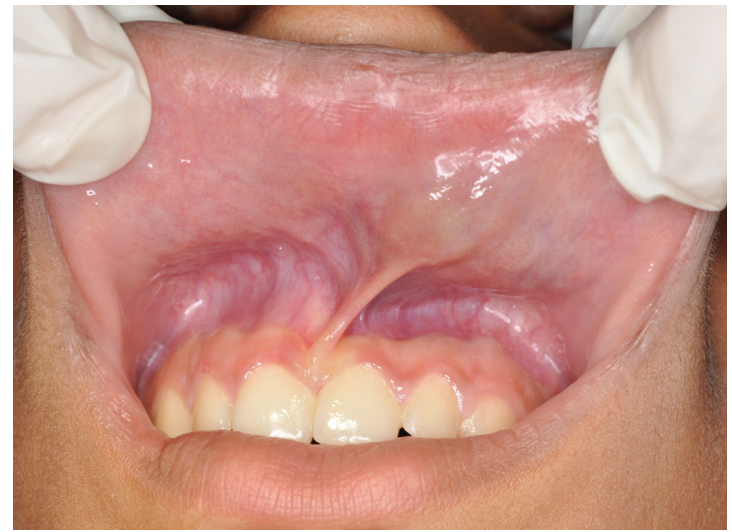

Figure 2. Physical examination, intraoral view.

center of the lesion with 1 week intervals between applications (Figure 4).

At a 4-month follow-up visit (Figure 5), favorable involution was observed, with localized fibrosis present. Currently, at 1-year follow-up, regression of the tissue fibrosis can be observed and the lesion has reduced significantly in size, in comparison with its initial appearance, with satisfactory esthetic results (Figure 6).

\section{DISCUSSION}

Oral hemangiomas are most common in the regions of the lips, tongue and buccal mucosa, presenting as red, purple or violet macules or nodules of variable size, which may be well-delineated or diffuse and are relatively depressible. ${ }^{3,4,6,8}$ In the case described here, the lesion was located on the left side of the upper lip, with no significant changes to extraoral appearance and discrete volume increase. However, intraorally, there was palpable increased volume and purplish coloration.

Hemangiomas can have onset during childhood or adulthood and are etiologically linked to genetic causes or to traumas at the site of the lesion. ${ }^{7-9}$ According to Neville et al., there is a 3 to 1 preference for females. ${ }^{2}$ In contrast, Angelo et al. ${ }^{7}$ observed higher prevalence among males at 54\%, while Johann et al. ${ }^{13}$ observed higher prevalence among females, at $59 \%$. The patient described here was within the age group that Angelo et al. ${ }^{7}$ say is most affected (adolescents aged 13 to 18 years). This patient also described having a habit of biting her upper lip, which is possibly the source of the trauma that caused the lesion.

Treatment of hemangiomas is dependent on their location, size and nature (venous or arterial). Therefore, correct diagnosis is of fundamental
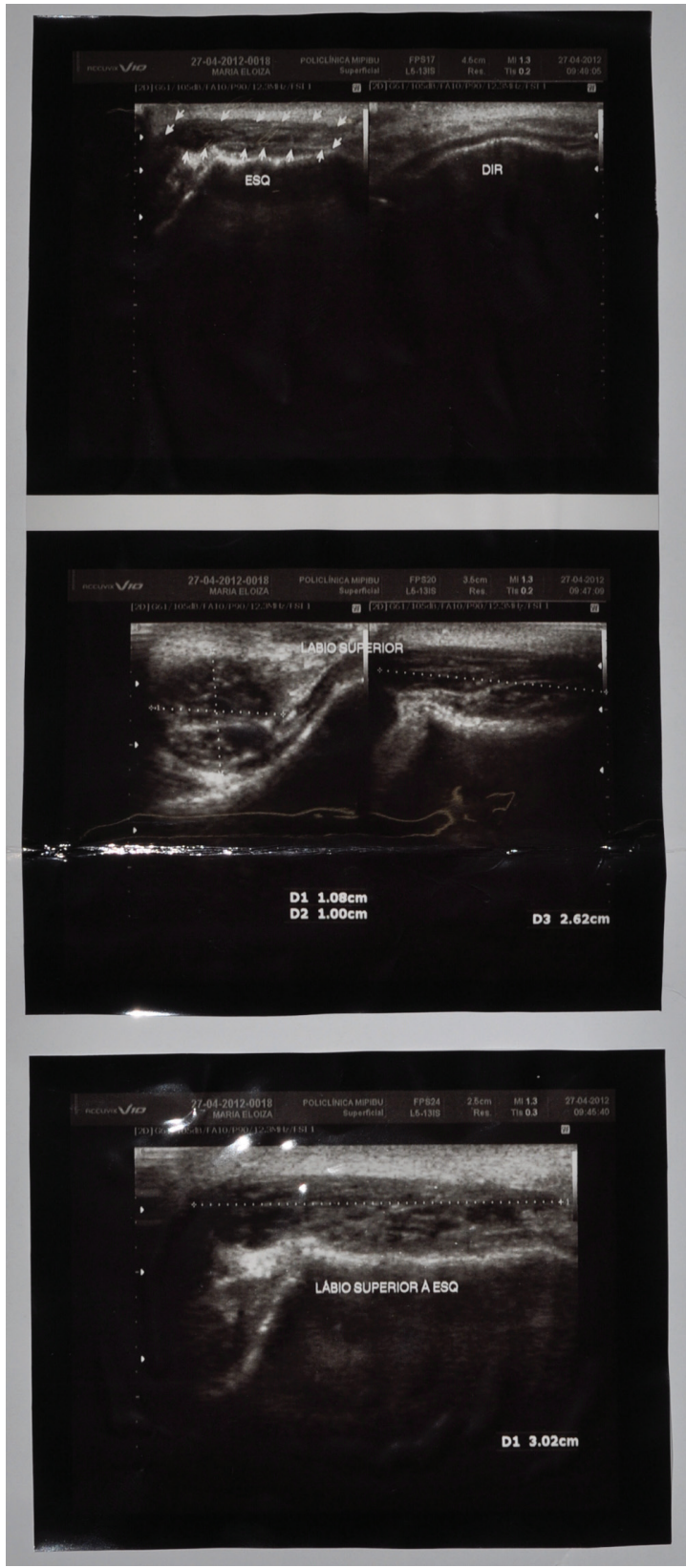

Figure 3. Ultrasonography examination.

importance. ${ }^{2,14}$ In the case described here, the clinical characteristics suggested a diagnosis of hemangioma and were supplemented by the imaging exam (Ultrasound with Doppler). On diascopy, the lesion blanched under glass in response to pressure and reduced in size, as the blood vessels emptied, differentiating it from other lesions, such as cysts and mucocele, which would not have blanched. Although this test can simplify diagnosis greatly, there are certain areas, such as the gingiva and the palate, where the technique is difficult to perform. ${ }^{8,9}$ 


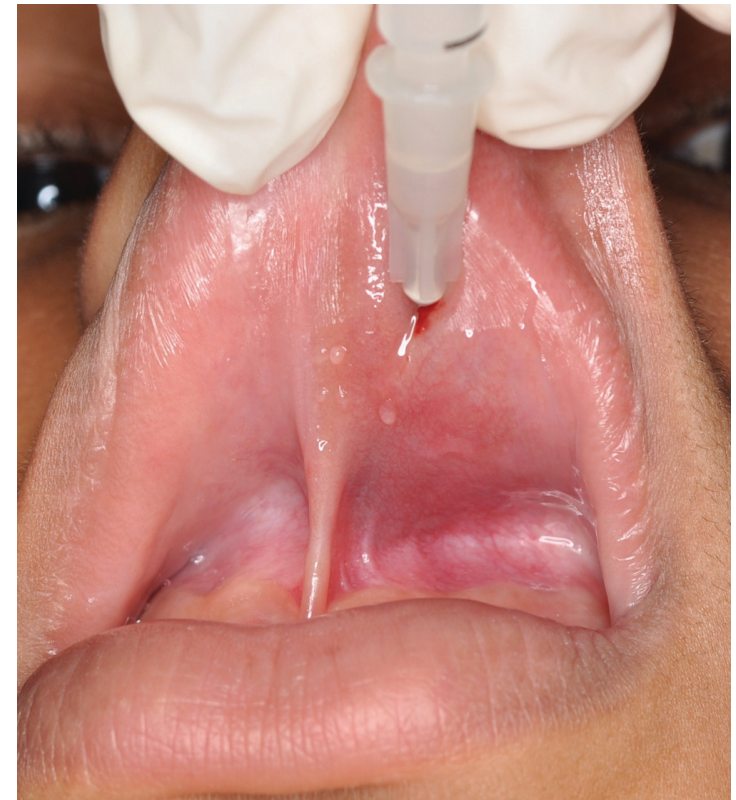

Figure 4. Administration of the sclerosing agent: monoethanolamine oleate $0.05 \mathrm{~g} / \mathrm{mL}$.

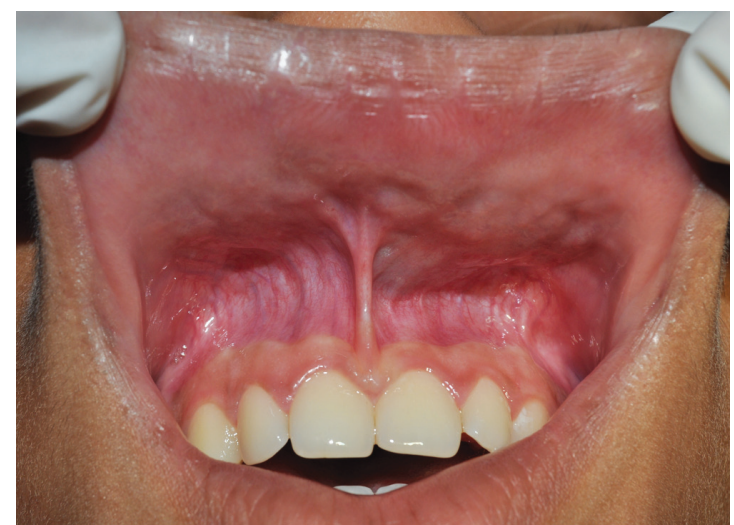

Figure 5. Four-month postoperative appearance.

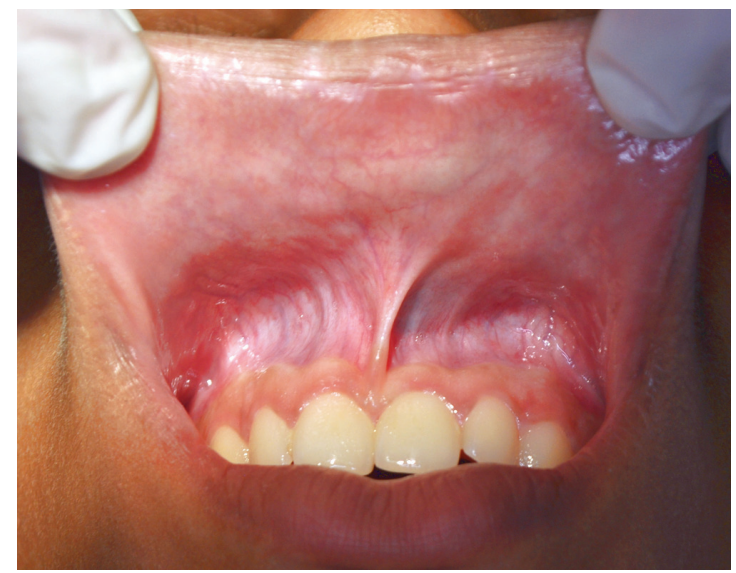

Figure 6. Twelve-month postoperative appearance.
Supplementary tests such as ultrasonography with Doppler may be needed to determine the nature of the blood supply to the lesion (arterial or venous), and can also aid with diagnosis. ${ }^{5}$ The ultrasonography examination requested for the case described above confirmed the suspicion of hemangioma. The Doppler study revealed discreetly dilated vessels with low resistance flow and identified the lesion as venous in nature.

Lesions on the face cause esthetic problems and become constant complaints while patients wait for involution of the lesion to take place, which can take a long time, depending on patient response. ${ }^{14}$ In view of this, several different treatment methods have been employed in attempts to control growth and bring forward regression of hemangiomas, depending on size and site. ${ }^{2}$ For smaller and peripheral lesions, treatment options include sclerotherapy, conventional surgical excision, laser treatment, radiotherapy, electrocoagulation and cryotherapy., ${ }^{3,4,12,15}$ For larger and/or intraosseous, lesions located in areas with esthetic impact, treatment should consist of embolization or obliteration of the lesion and adjacent vessels; indicated with the objective of achieving involution of the lesion for a subsequent surgical procedure. ${ }^{5,15,16}$

Sclerotherapy is the safest method, offering partial or total regression of the lesion, facilitating resection in a subsequent surgical intervention, if this proves necessary. In some cases, sclerotherapy may be the definitive treatment, achieving total regression of the lesion. Possible sclerosing agents include sodium morrhuate, sodium psylliate, hypertonic glucose solution, sodium tetradecyl sulphate and ethanolamine oleate. ${ }^{6,11,12}$ Throughout its history, Oral Medicine has sought procedures that minimize patient morbidity and has found a valuable ally in this type of treatment.

Although sclerotherapy is a simple technique that is apparently free from complications, special precautions must be taken. The sclerosing agent should be administered using an insulin needle, injecting the solution into the middle of the lesion, to avoid necrosis of surrounding tissues. ${ }^{6,10,11}$ The quantity injected will depend on the dimensions of the lesion, but, as a rule, should not exceed $2 \mathrm{~mL}$. Treatment may involve one or more applications, depending on the extent of the lesion and on the results, which should be evaluated when the next dose is administered, after an interval of 1 to 2 weeks. ${ }^{6,11,13}$

Sclerotherapy is contraindicated in uncontrolled diabetic patients and in areas of secondary infection. Administration of monoethanolamine oleate is 
contraindicated in expectant mothers, because it can have teratogenic effects. In addition to causing tissue necrosis, injection of volumes greater than the recommended can trigger anaphylactic reactions in patients who are sensitive to the drug. ${ }^{1}$

\section{CONCLUSIONS}

Vascular injuries in the head and neck are complex pathologies that are unlikely to be resolved if inappropriate treatment is chosen. Sclerotherapy is, without doubt, a feasible treatment method that can effectively resolve this type of vascular neoplasm, providing it is correctly indicated on the basis of its benefits and limitations. In the case described here, administration of the sclerosing agent monoethanolamine oleate provoked rapid and safe involution of the lesion, using a non-surgical method that is more likely to lead to the patient's esthetic recovery.

\section{REFERENCES}

1. Mulliken JB, Glowacki J. Hemangiomas and vascular malformations in infants and children: a classification based on endothelial characteristics. Plast Reconstr Surg. 1982;69(3):41222. http://dx.doi.org/10.1097/00006534-198203000-00002. PMid:7063565

2. Neville BW, Damm DD, Allen CM, Bouquot JE. Patologia epitelial. In: Neville BW, et al. Patologia oral \& maxilofacial. Tradução de Danielle Resende Camisasa. 3rd ed. Rio de Janeiro: Elsevier, 2009. p. 363-453.

3. Açikgöz A, Sakallioglu U, Ozdamar S, Uysal A. Rare benign tumours of oral cavity-capillary haemangioma of palatal mucosa: a case report. Int J Paediatr Dent. 2000;10(2):161-5. PMid:11310103.

4. McHeik JN, Renauld V, Duport G, Vergnes P, Levard G. Surgical treatment of haemangioma in infants. Br J Plast Surg. 2005;58(8):1067-72. http://dx.doi.org/10.1016/j.bjps.2005.04.029. PMid:16039624

5. Assis GM, Silva S, Moraes P, Amaral J, Germano A. Hemangioma de língua: relato de caso. Rev Cir Traumatol Buco-Maxilo-fac. 2009;9(2):59-66

6. Hou J, Wang $M$, Tang $H$, Wang $Y$, Huang $H$. Pingyangmycin sclerotherapy for infantile hemangiomas in oral and maxillofacial regions: an evaluation of 66 consecutive patients. Int J Oral Maxillofac Surg. 2011;40(11):1246-51. http://dx.doi.org/10.1016/j. ijom.2011.07.906. PMid:21893396

7. Angelo A, Moraes J, Rosa M, Duarte R, DeBiase R. Incidência de hemangioma na região de cabeça e pescoço em pacientes com a faixa etária entre 18 anos: estudo de 10 anos. Rev Odontol Univ Cid São Paulo. 2008;20(2):209-14.

8. Toledo H, Castro E, Castro A, Soubhia A, Salvador FB Jr. Hemangioma cavernoso de lábio inferior: caso clínico. Rev Odontol Araçatuba. 2004;25(1):9-11.
9. Prado B, Trevisan S, Passarelli D. Estudo epidemiológico das lesões bucais no período de 5 anos. Rev Odontol Univ Cid São Paulo. 2010;22(1):25-9.

10. Zanettini I, Zanettini RM, Gollo G. Escleroterapia como alternativa de tratamento de lesões vasculares bucais. Clin Pesq Odontol. 2005;2(2):119-26.

11. Selim H, Selim A, Khachemoune A, Metwally SAFA. Use of sclerosing agent in the management of oral and perioral hemangiomas: review and case reports. Med Sci Monit. 2007;13(9):CS114-9. PMid:17767124.

12. Seo J, Utumi E, Zambon C, Pedron I, Rocha A. Escleroterapia de hemangioma labial. Rev Odonto. 2009;17(34):106-12.

13. Johann AC, Aguiar MC, do Carmo MA, Gomez RS, Castro WH, Mesquita RA. Sclerotherapy of benign oral vascular lesion with ethanolamine oleate: an open clinical trial with 30 lesions. Oral Surg Oral Med Oral Pathol Oral Radiol Endod. 2005;100(5):579-84. http://dx.doi.org/10.1016/j.tripleo.2004.12.021. PMid:16243243

14. Lloret P. Tratamiento médico de los hemangiomas. An Sist Sanit Navar. 2004;27(1, Suppl 1):81-92. PMid:15148514.

15. Gómez Z. Hemangiomas. Tratamiento. Resultados en 15 casos tratados. Acta Odontol Venez. 1984;22(2):105-20. PMid:6598733.

16. Loureiro CC, Falchet PC, Gavranich J Jr, Lobo Leandro LF. Embolization as the treatment for a life-threatening mandibular arteriovenous malformation. J Craniofac Surg. 2010;21(2):3802. http://dx.doi.org/10.1097/SCS.0b013e3181cfa62a. PMid:20186078

Correspondence Salomão Israel Monteiro Lourenço Queiroz Universidade Federal do Rio Grande do Norte, Departamento de Odontologia Avenida Senador Salgado Filho, 1787 CEP 59056-000 - Lagoa Nova (RN), Natal Fone: (84) 96006633 E-mail: salomaoisrael10@gmail.com

Author information SIMLQ are VDS MSc candidates (Dentistry) at the Graduate Program in Public Health, Department of Dentistry, Universidade Federal do Rio Grande do Norte (UFRN).

GMA is a resident in Oral and Maxillofacial Surgery and Traumatology at Hospital Universitário Onofre Lopes, Department of Dentistry, Universidade Federal do Rio Grande do Norte. ARG and JSPS are Professors of Oral and Maxillofacial Surgery and Traumatology at Hospital Onofre Lopes, Department of Dentistry, Universidade Federal do Rio Grande do Norte (UFRN)

Author contributions Conception and design: SIMLQ, GMA, VDS Analysis and interpretation: SIMLQ, GMA, VDS Data collection: SIMLQ, GMA, VDS Writing the article: SIMLQ, GMA, VDS Critical revision of the article: GMA,VDS, ARG, JSPS Final approval of the article*: SIMLQ, GMA,VDS, ARG, JSPS Statistical analysis: N/A

Overall responsibility: SIMLQ, GMA,VDS, ARG, ISPS Obtained funding: None.

* All authors have read and approved of the final version of the article submitted to J Vasc Bras. 